\title{
Unpacking the Information, Media, and Technology Skills Domain of the New Learning Paradigm
}

\author{
Dr Charles Kivunja $^{1}(\mathrm{PhD})$ \\ ${ }^{1}$ Senior Lecturer in Pedagogy and Educational Leadership, Researcher: Embedding Social Media Technologies in \\ Pedagogy, Manager Leximancer Qualitative Software, School of Education, The University of New England, \\ Armidale, 2351, New South Wales, Australia \\ Correspondence: Dr Charles Kivunja, Senior Lecturer in Pedagogy and Educational Leadership, School of Education, \\ The University of New England, Armidale, 2351, NSW, Australia. Tel: 61-412-466-184 E-mail: \\ ckivunja@une.edu.au; c.kivunja@bigpond.com
}

Received: January 6, 2015

Accepted: January 17, 2015

Online Published: January 23, 2015

doi:10.5430/ijhe.v4n1p166

URL: http://dx.doi.org/10.5430/ijhe.v4n1p166

\begin{abstract}
Put simply, "Teaching our students so that they become well-equipped with the 21 st century skills is the new learning paradigm" (Kivunja, 2014b, p. 85). These skills fall into four domains which the Partnership for 21st Century Skills (P21) identify as the Traditional Core Skills, the Learning and Innovation Skills, the Career and Life Skills, and the Digital Literacy Skills; also known as the Information, Media, and Technology Skills (P21, 2009). Arguing that the traditional core skills, such as reading, -riting, and -rithmetic are well known, and might need no elaboration, Kivunja (2014b) discussed the Learning and Innovations Skills domain, and Kivunja (2015a) unpacked the Career and Life Skills domain. This paper unpacks the Digital Literacy Skills domain to extend an understanding of this domain in three ways. First, what is it and what skills does it involve? Second, how can students be taught the skills of this domain so they will be job ready to use these skills on graduation? Third, what is the significance of this domain to each of the other domains; and therefore to the success of studying, working, living and being a productive citizen in the realities of the Digital Economy?
\end{abstract}

Keywords: Partnership for $21^{\text {st }}$ century skills, Information literacy skills, Communication media literacy skills, Digital technologies literacy skills, New Learning Paradigm, Learning pyramid

\section{Introduction}

\subsection{Literature Highlighting the Need to Teach Students Information, Media, and Digital Technology Skills}

The most defining characteristic of the $21^{\text {st }}$ century is that it abounds with a proliferation of information, presented in a wide variety of multiple communication media and driven by diverse digital technologies. As noted by Wagner (2010) "In a very short period of time, with the advent of the Internet and the increasing availability of fast connections, we have evolved from a society where only a few people had limited information to one where all of us experience information flux and glut - and can look up almost anything imaginable on our computer in a search that takes nanoseconds" (p. 37). And it is not just computer-based searches and connections but, particularly in the last "20 years, the landscape of digital media [has] changed dramatically through mobile media (i.e. portable media players and mobile phones), believed to be the most rapidly adopted technology in history" (Squire, 2013, p. 187). In particular, the relatively young people born since 1980 that Tapscott (1998) calls "the Net Generation" (p. 15) and who constitute the majority of our students, are immersed in these technologies as they network and collaborate with one another via the World Wide Web. They are intricately tethered to the Internet and to a large variety of instant information, communication media and information tools that provide always-on Internet connectivity. Many researchers believe that these media and technologies are "the multiple literacies [which] provide a bridge between the real-life texts of the community and school learning.... Using a multiple literacy approach to classroom instruction enables students to understand, use and critically evaluate the multimodal texts of the $21^{\text {st }}$ century" (Kolb, 2008, p. 4). The significance of this bridge is highlighted very well by Moje (2000) when she says:

We can become more aware of what adolescents can do and the power and sophistication of those practices .... If we re-conceptualize our literacy theory, research and pedagogy to acknowledge the tools at use for making meaning in unsanctioned practices, to work with the strengths that our students already posses, and to teach 
students how to navigate the many discursive spaces called for in new complex times ... then we may be able to teach students tools that provide them with opportunities to be part and to construct multiple stories in many different social worlds. (p. 685)

Thus, training of students in multiliteracies (The New London Group, 1996), to equip them with information, media and digital technologies skills is cast by these researchers as a bridge that can give students better opportunities to connect their real-life experiences in the community to those in schooling contexts. For example, at http://www.google.com.au/edu Google has created an education suite of Google Apps which have potential to "bridge the divide between learning at home or at school, [and ] make it easy to share with fellow students, teachers, parents and the wider community" (Speranza, 2014, p. 53). Similarly, Channdler-Olcott and Mahar (2003) argue that the integration of these technologies skills into everyday schooling or learning contexts has potential to arouse more academically related interests within the school. This is certainly understandable when you consider the results of studies such as that by Lenhart, Madden \& Hitlin (2005) which found that $87 \%$ of youth aged $12-17$ are online, every day utilizing these media and technologies. As noted by Hirsch (1987), "advancing technology, with its constant need for fast and complex communications, has made literacy ever more essential [as a bridge] for commerce and domestic life" (p. 3). Also in support of teaching students media, information and digital technologies skills is Bruce (1997a) who strongly argues that there is a great need to embrace and to acknowledge these relatively new technologies for use in teaching rather than discourage their use or simply ignore them. He robustly proposes that students' success will highly depend on their ability to use these technological tools in various knowledge-building communities.

Whereas success of new ventures in the classical capitalist economy of the $20^{\text {th }}$ century Industrial Economy depended largely on investments in financial capital (Smith, 1776), the current Information-intensive, New Media, Digital Economy, has changed the equation enabling new ventures to succeed with relatively little investment in initial financial capital, (as perhaps best illustrated by Mark Zuckerberg's [1984-] phenomenal success with Facebook), provided they can excel in investing in information, media and digital technologies, which Moje and Sutherland (2003), regard as a form of cultural capital.

When it comes to teaching and learning, Trilling and Fadel (2009) propose that such cultural capital comprising huge amounts of information, media and digital technologies has potential to offer students "unprecedented power to amplify their ability to think, learn, communicate, collaborate, and create" (p. 64). However, if students are to realize that potential they must learn the skills necessary to understand, manage and use the massive amounts of information, media and technology.

It is essential, therefore, that students be taught these skills. As cogently articulated in The Australian and New Zealand Information Literacy Framework (Bundy, 2004), the existence of and access to these resources:

raises questions about authenticity, validity and reliability. ...[There are].. special challenges in evaluating, understanding and using information in an ethical and legal manner. The uncertain quality and expanding quantity of information, also pose large challenges for society. Sheer abundance of information and technology will not in itself create more informed citizens without a complementary understanding and capacity to use information effectively. (p.3)

Moreover, the need to use information, media and digital technologies in school contexts exists, not just for students, but for teachers as well. For example, a study that investigated access to computer hardware, the Internet, data servers and digital equipment and their use in high schools in the USA (Cuban, Kirkpatrick \& Peck, 2001), found that whereas state and federal governments had spent very large sums of money to provide access, this had not led to widespread use of these technologies in the teaching, learning and assessment facilitated by teachers at the respective schools. This apparent paradox suggests that there is a need to teach information, media and digital technologies skills not only to students, but also to teachers both still in training and those in-service.

Crucially, as Marc Prensky (2010) so eloquently articulates:

today's students' number-one complaint is that too many of their teachers just talk, and talk and talk. And unfortunately, the students' response is almost always to tune out.

So the era in which ... lecturing, presenting, explaining to all, or telling ... has pretty much come to an end .... This method [of teaching] is no longer relevant, because students are no longer listening... students are not there to receive what their teachers are delivering. ...Designed by their $21^{\text {st }}$ century upbringing, - especially by the Internet and complex games they play to explore and find out for themselves what works- [students] explore and find out for themselves what works. The consensus among experts is clear. The way for us to 
succeed under such conditions is for students to focus on using new tools, finding information, making meaning, and creating, and teachers must focus on questioning, coaching and guiding, providing context, ensuring rigor and meaning, and ensuring quality results. (pp. $10-11$ )

This was very much the case in the teaching of mathematics, for example, where Mouza and Lavigne (2013) found that when students were given opportunity to learn for the first time about the mathematical idea of slope, those that used the symbols fast approach struggled with the concept. However, those that used digital technologies understood this concept more easily and thoroughly because the technologies created "dynamic-representation environments [which] provided a way to break free from the symbols first approach, fostering interactions" (p. 17), which facilitated students' grasp of the concept. And so these authors concluded that "by leveraging now-common digital and computational technologies, we can engage more students in more meaningful mathematics, resulting in deeper learning" (Mouza \& Lavigne, 2013, p. 17). The literature reviewed in this section suggests that the Information, Media and Technology Skills Domain of the New Learning Paradigm needs to be well understood because it appears to have considerable potential for positive impacts on pedagogy. This is the focus of the rest of this paper.

\section{The Information, Media, and Technology Skills Domain/The Digital Literacy Skills Domain}

As well explained in Kivunja (2014c) the New Learning Paradigm comprises "the skills, knowledge and expertise, which need to be effectively taught, and which students must master to be well prepared for success in the Digital Economy" (p. 40). Those skills fall into four domains, which the Partnership for 21st Century Skills (P21), (P21, 2009; P21, 2011), identify as the Traditional Core Skills domain, the Learning and Innovation Skills domain, the Career and Life Skills domain, and the Digital Literacy Skills domain; also known as the "Information, Media, and Technology Skills" (P21, 2009, p. 5), domain. The Learning and Innovations Skills domain and the Career and Life Skills domain were discussed at length in Kivunja (2014c) and Kivunja (2015a) respectively. This section unpacks the Information, Media and Technology Skills (IMTS) domain in two subsections. First, it articulates what this domain is. Second, it details the skills that comprise this domain. This is followed by another section that discusses how the skills of this domain can be taught.

\subsection{What is the Information, Media, and Technology Skills (IMTS) domain?}

As its name suggests, and according to the Partnership for $21^{\text {st }}$ Century Skills (P21, 2009), the IMTS domain comprises "a range of functional and critical thinking skills related to information, media and technology, which citizens and workers must be able to exhibit" (p. 5), to be successful in the $21^{\text {st }}$ century economy. The Partnership (P21), articulates the components of this domain as three literacies that they characterize as information literacy, media literacy and information, communication and technology (ICT) literacy. Stambler (2013) asserts that these "literacy skills - Information Literacy, Media Literacy and Technology Literacy - help students gain knowledge through reading as well as using media and technology. These skills also help students create knowledge through writing as well as developing media and technology" (p. 12). These three components of literacy skills are dealt with in the following three subsections, respectively, to shed light on the meaning of each of these sets of skills and on what each involves.

\subsection{Meaning and Components of the IMTS Domain}

\subsubsection{Information Skills of the $21^{\text {st }}$ Century}

Information skills are also referred to as information literacies and have been defined by many scholars and institutions (e.g., ACRL, 2000; Andretta, 2011; Bawden, 2001; Bruce, 1997b; Bruce, Edwards \& Lupton, 2006; Bundy, 2004; Kasowitz-Scheer \& Pasqualoni, 2002; Stambler, 2013; UNESCO, 2002;), in many different ways. Of these, one that appears to capture their meaning quite well is that by the Association of College and Research Libraries (ACRL, 2000) which refers to them as the abilities of individuals to understand and to recognize what information is needed, when it is needed, and where it can be found, critically evaluate its value, and be able to use it effectively for particular purposes, such as learning, creating new ideas and knowledge, and solving problems. Similarly UNESCO (2002) describes people that are well equipped with information skills as people who "know when they need information, and are then able to identify, locate, evaluate, organize, and effectively use the information to address and help resolve personal, job related, or broader social issues and problems" (n.p. para 3).

The Australian and New Zealand Institute for Information Literacy (ANZIIL) and the Council of Australian University Librarians (CAUL), stipulate the following twelve attributes that people with information skills are expected to have, (Bundy, 2004):

i. recognize a need for information 
ii. determine the extent of information needed

iii. access information efficiently

iv. critically evaluate information and its sources

v. classify, store, manipulate and redraft information collected or generated

vi. incorporate selected information into their knowledge base

vii. use information effectively to learn, and create new knowledge

viii. solve problems and make decisions

ix. understand economic, legal, social, political and cultural issues in the use of information

$\mathrm{x}$. access and use information ethically and legally

xi. use information and knowledge for participative citizenship and social responsibility

xii. experience information literacy as part of independent learning and lifelong learning. (pp. 3-4)

These attributes are embedded within four overarching principles that characterize information literate people articulated by Bundy (2004) as those people who:

- engage in independent learning through constructing new meaning, understanding and knowledge

- derive satisfaction and personal fulfillment from using information wisely

- individually and collectively search for and use information for decision making and problem solving in order to address personal, professional and societal issues

- demonstrate social responsibility through a commitment to lifelong learning and community participation. (p. 11)

Stambler (2013) defines information literacy simply as "the ability to identify what information is needed and the ability to locate, evaluate, and use information" (p. 20). He then goes on to suggest that:

Because technology has increased the intensity and complexity of literate environments, the twenty-first century demands that a literate person possess a wide range of abilities and competencies, many literacies. These-are multiple, dynamic, and malleable, [and include the abilities and competencies to]:

- Develop proficiency with the tools of technology

-Solve problems collaboratively and cross-culturally

-Design and share information for global communities

-Manage multiple streams of simultaneous information

-Create, critique, analyze, and evaluate multi-media texts

-Attend to the ethical responsibilities. (Stambler, 2013, p. 17)

With particular focus on literacies in higher education, the British Society of College, National and University Libraries (SCONUL, 2011) defines information literacies to include the ability to identify a need for information, assess the scope of the current knowledge, plan strategies for locating information, gather and evaluate information, manage information professionally and ethically, and present information in a way that creates knowledge. Similar to the British Librarians, the American Association of School Librarians (AASL, 2009) suggests that information skills in the $21^{\text {st }}$ century will require that people be able to access information efficiently and effectively, evaluate that information critically and competently, and be able to use the information accurately and creatively. Trilling and Fadel (2009) agree that "accessing, evaluating, applying, and managing information well, are just some of the skills that define $21^{\text {st }}$ century digital literacy" (p. 66).

The Partnership for $21^{\text {st }}$ Century Skills $(\mathrm{P} 21,2011)$ categorizes information skills into two broad types. The first are the skills to access and to evaluate different types of information. The second are the skills relating to the ability to use and manage information. The first category includes the ability to access information at the time it is needed (efficient information) and information that is relevant to the task on hand (effective information). The second category includes the ability to use information accurately and creatively in understanding a concept or solving a problem, the ability to manage the flow of information from a wide variety of sources and the ability to use or apply the information ethically and legally. These Partnership (P21)'s two very broad categories appear to provide a very 
good lens into information skills as defined or described by the other contributors outlined here because they emphasize not only the abilities to know what information is needed, but also where and how to find it, as well as when, and why, the information is needed.

\subsubsection{Media Skills of the $21^{\text {st }}$ Century}

Stambler (2013) defines media literacy skills as "the ability to question, analyze, interpret, evaluate and create media messages" (p. 20). The Partnership (P21) identifies two broad categories of media literacy skills essential for success in $21^{\text {st }}$ century learning, living and work. The first category of media literacy skills comprises the abilities to analyze media. This includes three sets of skills which the Partnership (P21, 2009) outline as:

i. Understanding both how and why media messages are constructed, and for what purposes

ii. Examining how individuals interpret messages differently, how media can influence beliefs and behaviors,

iii. Applying a fundamental understanding of the ethical and legal issues surrounding the access and use of media. (p. 5)

The second category is articulated by P21 as the abilities to create media products. P21 specify two sets of skills that comprise this category as the abilities to:

i. Understand and utilize the most appropriate media creation tools, characteristics and conventions,

ii. Understand and effectively utilize the most appropriate expressions and interpretations in diverse, multicultural environments. (P21, 2009, p. 5)

Learners in the $21^{\text {st }}$ century are confronted, in all their walks of life, by a huge amount of media resources. As Trilling and Fadel (2009) say, "the net generation, today's digital natives, are bathed in bits from birth, clutching remote controls, computer mice, and cell phones from an early age" (p. 69). Professor Peter Senge agrees when he says "Children know more about what's going on in the world today than their teachers, often because of the media environment they grow up in. They're immersed in a media environment of all kinds of stuff" (In P21, 2014b, p. 6). They thus have many media tools which they can use to communicate through for example, instant messaging, online chatting, mobile conversations, email, Blackberry devices, webcams, video games, digital media players, audio podcasts, Web sites, and many other network and digital media (Levin, Arafeh, Lenhart \& Rainie, 2002). Given the understanding from neuroscience studies that these media tools that children grow up with actually help to re-structure their brains, their thinking and how they view the world around them (Jukes \& Dosai, 2006; Prensky, 2001: Tapscott, 1998), it is of the utmost importance that students be taught the skills that will enable them to understand how best to access and utilize media of the $21^{\text {st }}$ century and in particular, how to apply them for complex learning tasks, critical thinking, creative tasks, problem-solving and for effective communication at school or college, at work and elsewhere in their lives.

\subsubsection{Technology Skills for the $21^{\text {st }}$ Century}

In Learning for the $21^{\text {st }}$ Century, the Program for International Student Assessment (PISA, 2003), defines ICT literacy as "the interest, attitude and ability of individuals to appropriately use digital technology and communication tools to access, manage, integrate and evaluate information, construct new knowledge, and communicate with others in order to participate effectively in society" (p.4). Stambler (2013) defines technology or digital literacy skills as "the ability to use digital technology, communication tools or networks to locate, evaluate, use and create information" (p. 20). Walsh, Lemon, Black, Mangan \& Collin (2011) define technology skills more widely by referring to them as:

a broad term that includes technological devices (such as computer software and hardware), [brackets in original text], related communication practices (such as social networking, emailing, game-playing) and the relationships that develop through the use of technology. ICT also encompasses applications of technology including the Internet, mobile phones, gaming, music and media production. (p. 4)

Focusing on $21^{\text {st }}$ century learning the Partnership P21, defines this set of skills as "the ability to use technology to develop $21^{\text {st }}$ century content knowledge and skills, in the context of learning core subjects" (P21, 2014a, p1). The Partnership (P21, 2009), then goes on to describe the skills of this set as the ability to apply technology effectively in three broad ways; namely:

- Use technology as a tool to research, organize, evaluate and communicate information

- Use digital technologies (computers, PDAs, media players, GPS, etc.), communication networking tools and social networks appropriately to access, manage, integrate, evaluate and create information to 
successfully function in a knowledge economy,

- Apply a fundamental understanding of the ethical/legal issues surrounding the access and use of information technologies. (pp. 5-6)

Thus, the skills of this sub-set include, not only the ability to capture, organize, store and exchange information, but also the ability to determine its usefulness and suitability for a given purpose, within an ethical and legal framework. From an educational lens, these skills focus on the technologies that have potential to support learning, teaching, assessment and curriculum development. In most educational contexts in a modern classroom or theater, technology skills are likely to include ability to work well with hardware such as interactive whiteboards, computers and flash drives; mobile devices, such as laptops, eTablets, cell phones, smart phones, and digital cameras; software, such as word processors, spreadsheets, databases, web browsers, firewall and email, photo and video editors, and learning games for various subjects including maths, science and language; and of course the Internet which creates opportunities to access search engines, create products such as blogs, wikis, podcasts, social bookmarking sites, video conferencing, social media networking, and video streaming (Churchill et al., 2013).

\section{How Can the Abilities of the Information, Media, and Technology Skills Domain be Taught?}

James Gee (2007) put it well when he said "popular culture today is more complex than ever, and, in some cases, it appears that young people are learning in more innovative and powerful ways out of school than in" (p. xvii). Most of the innovative ways that Gee alerts us to reside within the Information, Media and Technology Skills (IMTS) domain of the New Learning Paradigm. As Trilling and Fadel (2009) clearly state, there is every "reason that our $21^{\text {st }}$ century students need to acquire the skills to appropriately access, evaluate, use, manage and add to the wealth of information and media they now have at their thumbs and fingertips" (p. 64). The Partnership (P21, 2014b) agree when they assert "In a digital world, students need to learn to use the tools that are essential to everyday life and workplace productivity" (p. 4). For this learning to happen, students should not be left on their own but taught well the abilities and capacities of the IMTS domain. For example, students need to be aware of the important distinction between primary and secondary sources of data and know how to assess the credibility of online information using corroborating evidence from multiple reliable resources.

Students need to be taught how to connect electronically with their peers using secure digital tools such as ePals, Nings, Social bookmarks, Special interest blogs (Prensky, 2010), Blogs, Wikis and Podcasts (Richadson, 2010), and relatively safe platforms such as Google Discussion Circles (Kivunja, 2015b). Teachers should show them, or encourage them, to set up peer learning networks, as the bases for connected learning communities. Today's students very quickly pick up new gadgets and work out how to use them. That is the nature of the Net Generation (Tapscott, 2009). As Solomon (2014) points out, "they are networkers and communicators; information, media and technology savvy, [and] reliant on media in various forms. For teachers to engage, educate, facilitate and motivate [them], their methods of teaching must be closely aligned to students' method of learning" (n.p. para. 6). It is therefore important that they be taught to be as self-regulated and self-monitoring learners (Zimmerman, 2000) as possible, so that they can use information, media and tecnologies, not only to take initiative, but also to keep track of the quality of their own learning.

As noted by Willingham (2009) "People are naturally curious" (p. 3) and if the cognitive conditions are right, they will engage in higher-order thinking. Creating the right cognitive conditions in an information rich, media saturated and digital tools driven classroom requires that the teacher's role should be to guide students and encourage them to discover and to follow their passions. The teacher's role should be to create opportunities for the students to use whatever communication media and digital technologies are available, to research and to find information that makes sense to them. Students should be given opportunity to make mistakes and to ask members of their peer learning networks questions that their peers can help them answer through cooperative learning driven by technologies to foster deeper learning (Johnston, 2014). As part of creating the right cognitive conditions, the teacher should contextualize learning, motivate the students, explain preferably on a one-to-one basis what needs to be done, and create high expectations of every student so that rigor and high quality learning, teaching, and assessment take place in this new way of pedagogical practice.

As explained well by Prensky (2010), the direct instruction method of teaching is antiquated, and is one of the main reasons students don't pay attention to teachers in class. In Why don't students like school?, Willingham (2009) also alludes to this outmoded teaching strategy as one of the possible answers to this question. In consideration of these leaders' views, teachers preparing students for the information rich, media fuelled and digital technologies driven workplace, should not simply tell them bits of information or knowledge, but give them questions to explore and to guide their curiosity as they search for answers by themselves. This suggestion is supported further by research 
conducted at the National Training Laboratories in Bethel, Maine, which developed what is popularly referred to as The Learning Pyramid illustrated in Figure 1, showing that students learn better and retain more information if they are taught using participatory strategies, such as group discussions, practice by doing and teaching others, rather than explicit instruction strategies, such as lecturing, reading, audiovisual illustrations and demonstration. As illustrated in Figure 1, whereas the participatory teaching methods resulted in retention rates as high as $90 \%$, the direct instruction, lecture method achieved only a 5\% retention rate. The message to pedagogues that is implicit in this Pyramid is clear. Since we know that today's learners are interested, and motivated by media and technologies of the $21^{\text {st }}$ century, (Jukes, McCain \& Crockett, 2010; Kelly, McCain \& Jukes, 2009; Kivunja, 2014a; Tapscott, 2009), and that they are relatively information, media and technology savvy (Solomon, 2014), the way to help them develop deeper skills of the IMTS domain, is firstly by educators using these technologies and showing students how to use them. Secondly educators should encourage learners to bring these media and digital tools to class, tutorial and lecture theatre, so that students may understand how to use them for learning and solving academic problems individually. Thirdly, and more importantly, by giving students opportunities to dialogue, communicate with each other and teach each other, using media and digital technologies, so as to facilitate and maximize their learning cooperatively and by teaching each other. These might sound like radical propositions, but they represent the paradigm shift that is needed to effectively implement the IMTS domain of the New Learning Paradigm. This is the challenge about which Gagne, Wagner, Golas and Keller (2005) admonish:

The explosive development of digital technologies has fundamentally transformed how, what, when, and where people learn.... Technology is affecting change in educational institutions... by posing new challenges to teachers and instructors, students and parents, and training developers need to rethink approaches to learning, education and training to determine how technology can support each. (p. 208)

Piaget's (1954) and Vygotsky's (1978) principle of student-centricity which emphasizes that students learn best when they are proactive and actively engaged in the construction of knowledge through doing, has never been more relevant than now, when we, teachers, equipped with information, media and digital technologies, have the opportunity to let students take the leading role in using these technologies for their learning. As more recent leaders in this field admonish, while "not losing sight of their responsibility as teacher, leader and role model in the class" (Dobozy, Bryer \& Smith, 2012, p. 291), teachers "must increasingly find a way to move towards a student-centric model" (Christensen, 2011, p. 38), which is believed to be "positively associated with a wide variety of positive student outcomes" (Dobozy et al. 2012, p. 291). To allow students to harness these outcomes, teaching methodologies should be designed to provide mentoring, coaching and guiding students' learning, and to assess the quality of learning that occurs in class as students use media and technology. This way, the use of these technologies in teaching and learning can create opportunities for formative assessment, which is believed to have significant potential to positively influence learning (Black \& Wiliam, 2009; Clarke, 2001; 2005; Yorke, 2003).

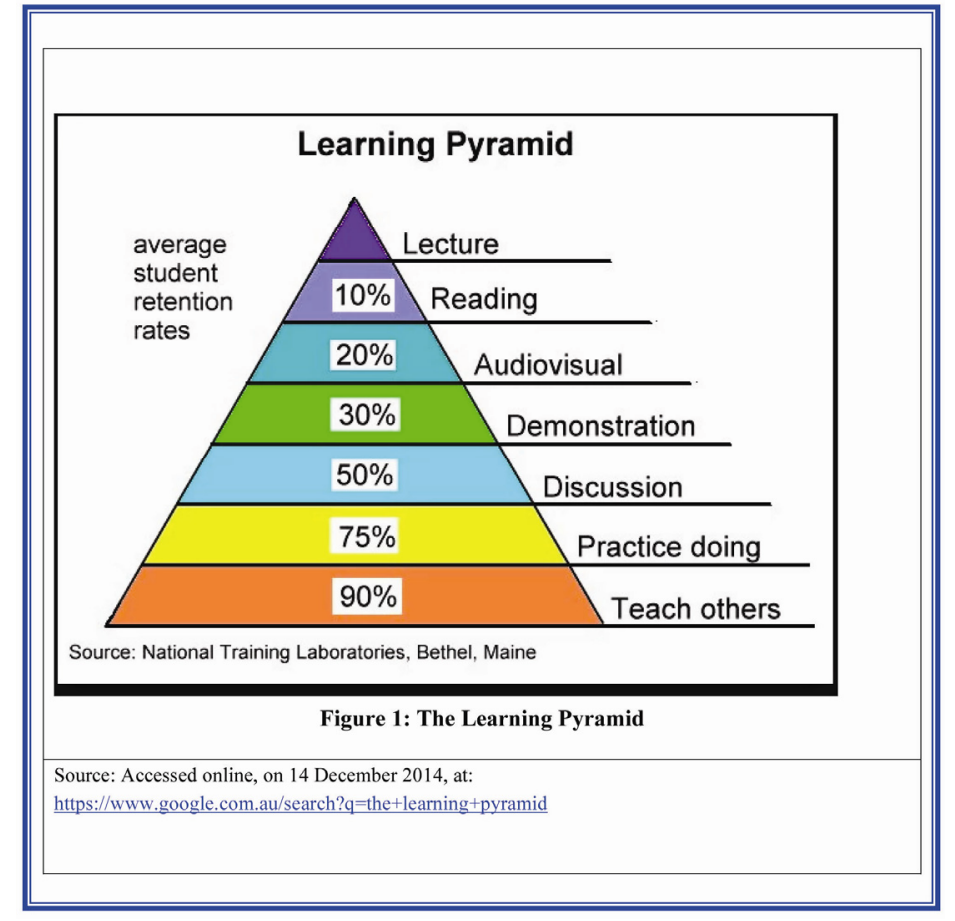


Teaching methodologies designed to help students master skills of the IMTS domain, particularly the digital skills, should take full advantage of Google Apps which, as Speranza (2014) explains, Google has purposely:

designed to help students and teachers work together more efficiently and effectively. ...At the core, Google Apps include Gmail (webmail service), Google Drive (online documents, spreadsheets, presentations, forms, and drawings), Google Calendar (web based appointments and organization) and Google Sites (website creator); not to mention the many additional services like Hangouts, Blogger, Youtube, or Picasa which can be used with Google Apps with seamless integration. As cloud-based technologies, they are always readily available, backed up, accessible at any time and place and available to use on any device. (p. 53)

We also know from the work of luminaries on how students learn such as Honey and Mumford (1982), Gardner (1983), Hartman (1995), and Cassidy (2004), that there are significant differences in the way students learn; and that they learn better if taught in their individual ways (Dunn \& Dunn, 1978). In particular, Hartman's (1995) work shows that the use of technology can cater well for the learning preferences of students. Although the traditional, direct instruction method of teaching that broadcasts the same message to all students simultaneously still has room and can in fact be used to effectively support learning (Binder \& Watkins, 1990), teaching with the modern information, media and digital technologies gives teachers the opportunity to let each student personalise their learning in their preferred way. In most cases, their preferred way involves the always-on Internet interconnected learning with peers, not only in the same class and school, but also with others from across the World Wide Web, on a 24/7 timeframe. With careful Unit design, prudent implementation and monitoring following Anderson's (2001) model, Kivunja's (2015b) recent research found that when students were given opportunity to learn using high-tech, digital technologies that allowed them to invite others to their peer learning networks, they were able to increase student participation in their discourses, so that they "enjoyed a very high participation multiplier effect of $470 \%$ " (p. 11). These outstanding results were achieved by students when they were given opportunity to use social media technologies in their learning and assessment tasks. Since social media are among the most preferred platforms for students' communication (ACMA, 2013), teaching methods which encourage their use in learning have potential to make pedagogy more authentic, by "aligning authentic learning environments, with assessment, students' approaches to thinking and learning outcomes" (Meyers \& Nulty, 2008, p. 1).

To teach students how to learn using information, media and digital technologies requires that teachers be flexible and empathetic and allow students to use these technologies to learn in their own way. In line with what Dobozy et al. 2012) say, this approach requires:

that teachers are empathetic towards students, try to express warmth and genuine concern for their students' well-being and try to focus on student concerns and issues, ... [teachers can achieve this] by simply taking the students' perspective on a given situation, [and asking themselves], If I were the student here, what would I want? What would I be looking for? (p. 291)

It is therefore critical in the teaching of the IMTS that teachers carefully consider different ways to incorporate some of the numerous information, communication media and social networking technologies into curricula so as to support and stimulate their students' interest in using these technologies for learning and assessment. This implies that you, as the teacher, learn to appreciate your students' new approach to learning and to show that you value and respect what they discover using these new technologies. What they discover, replaces what they could have been asked to cram or to memorize, without taking the trouble to find it and to figure out what it means. And because of this knowledge acquisition process, not only are students more inclined to apply Bloom's (1956) higher-order cognitive levels of analyzing, evaluating and creating what they discover, but to also feel empowered as they determine what information is relevant and how to share it with their peer learning networks. They have to decide, for example, whether to email, to blog, text, tweet, chat, use forums, Google Discussion Circles, or some other technologies; and who they are to network with. This approach to teaching does not imply relinquishing your role as leader of learning, but rather, that you develop your skills in information, media and digital technologies so that you improve your digital fluency and can guide your students' learning effectively. With improved digital fluency, you can better play the role of mentor and coach, as students engage in self-teaching activities.

A criticism that is sometimes labelled against the use of these digital technologies is that they do not encourage students to think deeply, because students simply click, click and go, "with no concern for achieving broader and deeper connections across related problems, concepts and representations" (Roschelle, Courey, Patton \& Murray, 2013, p. 31). This criticism seems to overlook the fact that teaching students to use these media does not simply show students where to click to find the information, but raises questions and sets up problems for them to solve as they find relevant information on the Web. Students appear to rise to the challenge as evidenced in Kivunja's (2015b) 
study in which students actually took the initiative to find new learning resources and then shared them with their peers to teach them or to help them learn. Teaching like this requires careful planning such as that which was used by a group of teachers of mathematics who designed digital texts to help teachers and students focus on mathematical thinking in five ways:

i. making sense of students' thinking,

ii. helping learners to express multiple approaches to solving mathematical problems,

iii. using representations and technologies insightfully to explore mathematical meaning,

iv. structuring extended conversations with students around mathematical ideas, and,

v. developing their own ability to reflect articulately on their own sense making. (Roschelle, et al. 2013, p. 31)

Needless to say, students can now have access to massive amounts of data, by literally clicking a button on their desktop, laptop, eTablet or smart phone. But as teachers we need to understand that students need to be trained in contextualising the data that appear to be so easily available, and in how to process and analyse them to gain an understanding of what the data mean. Without proper training, counsel and guidance, students cannot be expected to correctly distinguish between social conversation and rigorous academic dialogue. Accessing information is simple and can be mechanical, or simply electronic. What is more important and requires serious training for our students is the ability to align the information with the learning outcomes, in order to achieve high standards in learning.

As said earlier, teaching students how to use these new technologies requires not only flexibility on your part but also respect for your students' discoveries from the Web. Not only does teaching children to use these new technologies require these attributes, it also requires that the teacher be prepared to learn from students. There will no doubt be instances, when students in a class will discover a new app before the teacher does. In instances like this, the teacher needs to be prepared to learn from the students and to show that $\mathrm{s} / \mathrm{he}$ appreciates the leadership demonstrated by the students. This kind of student leadership in learning can easily be appreciated by other students too as, "given the nature of structural-cultural dynamics" (Kivunja \& Power, 2006, p. 28), they are more likely to quickly align their thinking or their views with those of their peers than those of the teacher.

In developing the abilities of this IMTS domain, the teacher can no longer be what Professor Alison King (1993) described as "sage on a stage" (p. 30) with all the information to be given to students, but rather as a "guide on the side" (King, 1993, p. 30) to help students make sense of the information they discover by themselves. The information is readily available and teaching needs to provide guidance from the sideline to help students make sense of it for themselves, or with their peers, preferably, through social interactions. For example, in Playing to learn, Hutchison (2007), gives several vivid illustrations of how teachers can organise their students to interact with video games as pedagogical resources that can teach students about virtual worlds across all Key Learning Areas (KLAs), including English, mathematics, science and technology, creative arts, human society and its environments, personal development, health and physical education, and languages other than English. Following Resnick (2002), Gagne et al. (2005) also suggest "school classrooms of the $21^{\text {st }}$ century need to be reorganised so that students can become more active and independent, with the teacher serving as a consultant rather than a lecturer" (p. 210). The Partnership (P21, 2014b) agree when they say:

Because children now live in a world of almost unlimited and profound information, of enormous opportunity and difficult choices, helping students make vital practical, emotional and social connections to skill and content is more important than ever. To help students make these meaningful connections, teachers can create a $21^{\text {st }}$ century context for learning by ... Bringing the world into the classroom; Taking students out into the world; ... Today, technology makes it possible to bring the world into the classroom and to get students out into the world... Technology makes it possible to change the dynamic between students and teachers, allowing students to pursue topics in depth and, at times, become experts in charge of their own learning. (p.12)

There is an urgent need to teach students how to connect their smart phones and eTablets to their school work and their communities. As noted by Roschelle and Pea (2002), teaching students this way will help overcome the conundrum between traditional, highly centralised transmittal-learning approaches and deeply diversified approaches which give students opportunities to learn with a high level of autonomy and self-direction. As recommended by Resnick (2002), curricula in schools should be continually updated to reflect tasks and skills that align well with the skills of learners in the digital age. And so, in teaching learners of the digital age, it is important to give them the opportunity, for instance, to work with computer simulations so that learners can investigate for themselves how systems work. To teach learners in the digital age, "curricula need to be transformed to focus less on things to know and more on strategies for learning the things you don't know" (Resnick, 2002, p. 209). Therefore, emphasis should 
be put on helping students become more strategic learners, that can utilise the vast resources of the Internet to make meaning of material they are learning, rather than learning through memorising facts they are given.

Unlike teaching in the $20^{\text {th }}$ century when reading text was the major method of accessing information for learning, teaching learners the abilities of the IMTS domain requires an emphasis on a multimodal approach so as to develop students' skills in a wide area including, for instance, listening, ability to read graphs, ability to follow moving images, and multitasking, because the multimodal delivery system of the Internet offers opportunity for the stimulation and utilization of many types of stimuli. To help students develop skills in these areas, planning is of the utmost importance. For example Churchill et al., (2013) propose that such planning should include ensuring that you have enough computers for all your students to be engaged during the lesson, timetabling to allow each child a reasonable amount of time to work with the computer, and making sure that the aims of the lesson are very clear to all students. It should also ensure that you have prepared the students well enough so they have the necessary skills and confidence to complete the computer-assisted task. You should also plan for ability to provide technical support as needed by the students, ensuring that the computers and the software on them works. You should articulate very clearly the rules governing the use of the computers so the students know what they can and what they can't do, and of course, you should be prepared to stand back and let students have a go without unnecessary interruption from you. This "letting go" (Churchill et al., 2013, p.318) should avoid 'the one size fits all' approach of the traditional instructional approach and allow students to personalise their approaches to learning so they can progress through the learning tasks according to their individual learning styles (Dunn \& Dunn, 1978), using different approaches (de Bono, 1992), skills, and orientation (Gardner, 1983), and timing that suits them. Teaching students using this approach will enable us to replace the antediluvian model of learning between 9am and 3pm and alone with one whereby students learn through interactions of the IMTS domain connected to other learners by the Internet in peer learning networks and learning through $24 / 7 / 365$ by convenient arrangements.

While students should be encouraged to personalise their learning using digital technologies, they should also be taught about the need to develop and to protect their personal digital identity and reputation by setting up their digital profiles to private (rather than public) and not revealing their passwords. They should be taught about the potential dangers of working on the Internet and how to protect their personal information. This type of teaching is essential because, as illustrated in a study of Young Australians' experiences of social media (ACMA, 2013) it was found that "a large proportion of young people have shared their computer or mobile device passwords with someone else" ( $p$. 9). This problem appears quite common as Tapscott (2009) also noted, "Net Geners are making a serious mistake, and most of them don't realise it. They're giving away their personal information on social networks and elsewhere and in doing so are undermining their future privacy" (p. 7).

It is important to teach students about online safety, risks and risky behaviours which they should avoid while in the online environment. This was well illustrated in another Australian study where undergraduate students who studied and completed assessment tasks using Google + Discussion Circles social media technologies were given strict instructions to always work in the 'private' and never in the 'public' areas of Google (Kivunja, 2015b). While students can benefit from working in always-on Internet interconnected environment in which most of the IMTS function, they need to be taught and cautioned about the possibilities of cyber bullying and offensive behaviours such as sexting and what to do if they come across such instances.

\section{What is the Significance of the Information, Media, and Technology Skills Domain in the Digital Economy?}

While it is important to preserve the essentials of education that made $20^{\text {th }}$ century learning and industrial workplaces great, there is an urgent need for educators, at all levels - preparatory, primary, secondary and tertiary - to embrace tools of the $21^{\text {st }}$ century involving information, media and digital technologies, as articulated in the IMTS domain of of the New Learning Paradigm. Although "schools are one of the slowest changing cultural institutions" (Gagne et al. 2005 , p. 210), it is important to realize that the Web's fundamental properties have "created a new kind of information fabric in which learning, working, and playing co-mingle" (Brown, 2000, p. 12). In this information fabric or domain, and with technology changing rapidly, the skills in this domain call for employees who can practice self-direction and continuous improvement. These are the skills that managers of $21^{\text {st }}$ century firms look for as well articulated by Wagner (2010) when he reports:

For our production and crafts staff, the hourly workers, we need self-directed people who either have problem-solving skills or can easily be trained to think on their feet and find creative solutions to some very tough, challenging problems. We no longer have supervisors who take control... and so we look for a different employee than a few years ago: one with critical thinking skills, creativity, mechanical aptitude and a passion to embrace new ideas. That is what we need for our workforce and our business to succeed in today's [digital 
economy]. (p. 19)

Without teaching students to master the skills of the IMTS domain of the New Learning Paradigm, teachers, schools, universities and nations will not be able to bridge what Wagner (2010) calls:

the global achievement gap - the gap between what even our best suburban, urban, and rural public schools are teaching and testing versus what all students will need to succeed as learners, workers and citizens in today's global knowledge economy.... In this newly flattened world, ... the universe in which our children must compete and succeed has been rapidly transformed by groundbreaking and rapidly evolving technologies. (p. 9)

As a result, "students today are partly shaped by their environment, which is media rich, immediate, fast, engaging, dynamic and instant. It is electronic and digital, a communication medium implying instant gratification" (Solomon, 2014, para. 4). It is therefore incumbent upon educators, particularly those in higher education, to equip students with the information, media and digital literacies skills that help to prepare them for success in the information rich, media saturated and technology driven $21^{\text {st }}$ century economy.

As stated at the start of this paper, the most defining characteristic of the $21^{\text {st }}$ century is the abundance of information presented in a wide variety of multiple communication media and driven by diverse digital technologies. In the workplace, employees have to manage massive amounts of information as part of their daily routines. As Mike Summers, vice president for Global Talent Management at Dell Computers articulated, "there is so much information available that it is almost too much, and if people aren't prepared to process the information effectively it almost freezes them in their steps" (Wagner, 2010, p. 36). Teaching students the skills of the IMTS domain will help alleviate such freezing. This is why Wagner (2010), refers to the ability to access and to analyze information as one of the essential skills needed for the survival of the American economy [and for any other economy in the $21^{\text {st }}$ century, digital world, I hasten to add].

It is important that the skills of this domain be taught well to students because, as Barbara McCombs (2000) asserts, "Numerous studies exist demonstrating that... educational technology appropriately applied can enhance learning and achievement compared to traditional teaching methods" (p. 1). Similarly, in a comprehensive review of literature on the use of information, communication and technology and its impact on attainment in schools in the UK, Cox et al., (2003) concluded:

The evidence from the literature shows the positive effects of specific uses of ICT on pupils' attainment in almost all the National Curriculum subjects. The most substantial evidence is in the core subjects of English, mathematics and science at all key stages. ... There is a strong relationship between the way in which ICT has been used and pupils' attainment. (p. 3)

This finding emphasizes the importance of ensuring that the abilities and capacities of the IMTS domain are taught well, not only in higher education, but also across all learning stages from $\mathrm{K}-12$ and beyond. Fetherston (2006) agrees with this finding when he says "ICT can have a positive effect on students' enjoyment and interest in learning. It can also result in increased commitment to the learning task, increased independence and motivation for self-directed study" (p. 315), and he extends the impacts beyond academics to include, "enhanced self-esteem and improved behavior" (p. 315). These impacts extend to all aspects of life as emphasized by NEA (2014) when they assert:

The power of modern media and the ubiquity of communication technologies in all aspects of life make teaching strong communication skills even more important. Students must be able to effectively analyze and process the overwhelming amount of communication in their lives today... And as technology gives rise to global work teams that span time zones, nations, and cultures, it is imperative that tomorrow's graduates communicate clearly in a variety of languages. (p. 13)

\section{Conclusion}

As well articulated by Richardson (2010) "For more than a hundred years we have defined being literate as being able to read and write. And although those core abilities are still central to learning, they are no longer enough to ensure understanding. ... the explosion of information and online technologies demands a more complex definition of what it means to be literate" (p. 148). In today's highly competitive knowledge economy, we are confronted with exponential increases of information that is available at the click of a button on a desktop, laptop, eTablet or smart phone, driven by new technologies that are constantly evolving at a phenomenal rate. To be literate and to be able to understand well and be productive members in today's knowledge economy students need to graduate from high school, college and university with skills that will enable them to have a fulfilling career and to contribute to the knowledge economy as productive citizens. High on the list of these skills are a range of functional and critical 
thinking skills of the Information, Media and Technology Skills domain discussed in this paper. Failure to equip graduating students with these skills will place them at a significant competitive disadvantage, in an age where such competition is more critical because it is in the global village, rather than just their own local village. It is therefore essential that students graduate, having been taught not only how to access useful information, but also how to analyze it, how to evaluate its trustworthiness, validity and reliability, how to use it to solve real life problems, and how to communicate its content effectively with clients in the local and global village.

There is no doubt that information availability, media and technology have an impact on how students live, interact with their family members, their peers and how they learn. We know, according to John Medina (2013) that "Every brain is wired differently. What you do and learn in life physically changes what your brain looks like - it literally rewires it" (p.41). Jones and Bartlett (2014) also assert, "Children's media and technology exposure affects how their brain works. A brain's wiring is structured according to the stimuli it is exposed to" (p. 33). This understanding has led some leaders in the field to suggest that because young people live and have grown up in this information, media and technology environment, they think differently and their brains are wired differently to those of earlier generations that did not grow up surrounded by information, media and technology (Jukes \& Dosai, 2006; Prensky, 2001; Tapscott, 1998). For example, Jukes and Dosai (2006) explain this quite well when they say:

A great deal of brain research, in what is called the neurosciences, has been undertaken in the past few years. This research has validating much of what we suspected from the psychological research, particularly the psychological sciences. The bottom line is that because of constant digital bombardment, because of the new digital landscape, and the pervasive nature of digital experiences, children today are growing up digital, [and] are FUNDAMENTALLY [upper case in original text], different from previous generations in the way they think, in the way they access, absorb, interpret, process and use information and above all, in the way they view, interact and communicate in and with the modern world. As a result of this, they're different in the way their brains are wired. (pp. $3 \& 14$ )

This highlights the responsibility that pedagogues have to make sure that their graduates are well equipped with the skills that will enable them to think, access and absorb, interpret and use information for their own good, in learning, at work, and citizenship in today's information, media and technology economy.

The current explosion of information, media and digital technologies means that if students are well educated in accessing and using the information wisely, and are able to take advantage of the vast array of media and technologies available, pedagogy will change, not only with regard to what we teach, but also to when, where and how we teach. Abilities and capacities of the IMTS domain can work as an accelerator and a multiplier of learning in all the domains of the New Learning Paradigm to give learners the opportunity to extend learning far beyond the classroom, tutorial and lecture theater. They have potential to make learning an enjoyable, lifelong experience beyond school and into the broader learning ecosystem comprising peer learning networks and a multiplicity of knowledge-building communities. However, if the full accelerator and multiplier potential of the IMTS domain is to be fully realized it must be conscientiously developed in concert with the development of foundational academic subject or content knowledge of the Traditional Core Skills domain, as well as the Learning Innovations Skills plus the Career and Life Skills of the New Learning Paradigm.

\section{References}

AASL. (2009). Standards for the $21^{\text {st }}$ century learner in action. Chicago: American Association of School Librarians, ALA.

ACMA. (2013). Young Australians' experience of social media: Quantitative research report, Australian Communications and Media Authority. Canberra: Australian Government.

ACRL(2000). Information literacy competency standards for higher education -Introduction. Association of College and Research Libraries. Accessed on 24 September 2013, at: http://www.ala.org/Content/NavigationMenu/ACRL/Standards_and_Guidelines/Information_Literacy_Compete ncy_Standards_for_Higher_Education.htm.

Anderson, M. D. (2001). Individual characteristics and Web-based courses, In C. R. Wolfe (Series Ed.), Learning and teaching on the World Wide Web. London: Academic Press, (pp. $45-72$ ).

Andretta, S. (2011). Information literacy: A term whose time has passed? Journal of Information Literacy, Vol. 5(1), pp. 1-4. http://dx.doi.org/10.11645/5.1.1630

Bawden, D. (2001). Information and digital literacies: A review of concepts. Journal of Documentation, Vol. 57(2), 
pp. 218-259. http://dx.doi.org/10.1108/EUM0000000007083

Binder, C. \& Watkins, C. L. (1990). Precision teaching and direct instruction: Measurably superior instructional technology in schools. Performance Improvement Quarterly, Vol. 3(4), pp. 74 - 96. http://dx.doi.org/10.1111/j.1937-8327.1990.tb00478.x

Black, P.J. \& Wiliam, D. (2009). Developing the theory of formative assessment. Educational Assessment, Evaluation and Accountability, Vol. 21(1), pp. 5 - 31. http://dx.doi.org/10.1007/s11092-008-9068-5

Bloom, B. H. (1956). Taxonomy of educational objectives, Handbook 1: Cognitive domain. New York: David Mackay.

Brown, J. S. (2000). Growing up digital: How the Web changes work, education and the ways people learn. Change, March/April, 2000. Accessed online on 9 December 2014 at: www.johnseelybrown.com/Growing_up_digital.pdf

Bruce, B. C. (1997a). Literacy technologies: What stance should we take? Journal of Literacy Research, Vol. 29, pp. 289 - 309. http://dx.doi.org/10.1080/10862969709547959

Bruce, C. (1997b). The seven faces of information literacy. Adelaide: Auslib Press.

Bruce, C., Edwards, S., \& Lupton, M. (2006). Six frames for information literacy education: A conceptual framework for interpreting the relationships between theory and practice. Accessed on line on 3 July 2012, at: http://www.ics.heacademy.ac.uk/italics/vol5-1/pdf/sixframes_final\%20_1_.pdf

Bundy, A. (Editor) (2004). Australian and New Zealand information literacy framework: Principles, standards and practice, (2nd edn.). Adelaide: Australian and New Zealand Institute for Information Literacy (ANZIIL) and Council of Australian University Librarians (CAUL).

Cassidy, S. (2004). Learning styles: An overview of theories, models, and measures. Educational Psychology, Vol. 24(4), pp. 420-444. http://dx.doi.org/10.1080/0144341042000228834

Chandler,-Olcott, K. \& Mahar, D. (2003). "Tech-savviness" meets multiliteracies: Exploring adolescent girls' technology-mediated literacy practices. Reading Research Quarterly, Vol. 38(3), pp. 356 - 385. http://dx.doi.org/10.1598/RRQ.38.3.3

Christensen, C. M. (2011). Disrupting class: How disruptive innovation will change the way the world Learns. New York: McGraw Hill.

Churchill, R., Ferguson, P., Godinho, S., Johnson, N.F., Keddie, A. \& Letts, W. (2013). Teaching: Making a difference. $\left(2^{\text {nd }} \mathrm{Edn}\right)$. Milton: John-Wiley.

Clarke, S. (2001). Unlocking formative assessment: Practical strategies for enhancing pupils' learning in the primary classroom. Abington: Hodder Education.

Clarke, S. (2005). Formative assessment in the secondary classroom. Abington: Hodder Education.

Cox, M., Abbott, C., Webb, M., Blakeley, B., Beauchamp, T. \& Rhodes, V. (2003). ICT and attainment: A review of the research literature. UK: BECTA.

Cuban, L., Kirkpatrick, H., \& Peck, C. (2001). High access and low use of technologies in high school classrooms: Explaining an apparent paradox. American Educational Research Journal, Vol. 38(4), pp. 813 - 834. http://dx.doi.org/10.3102/00028312038004813

de Bono, E. (1992). Six thinking hats for schools: Resource book 4. Melbourne: Hawker Brownlow Education.

Dobozy, O., Bryer, B. \& Smith, R. (2012). Educational psychology, (1 $1^{\text {st }}$ edn.). Milton, Qld: John Wiley.

Dunn, R. \& Dunn, K. (1978). Teaching students through their individual learning styles, Reston VA: Reston.

Fetherston, T. (2006). Becoming an effective teacher. South Melbourne: Thomson.

Gagne'. R. M., Wagner, W. W., Golas, K. C. \& Keller, J. M. (2005). Principles of instructional design, (5 ${ }^{\text {th }}$ Edn.). Belmont, CA: Cengage Learning.

Gardner, H. (1983). Frames of mind: The theory of multiple intelligences. New York: Basics Books.

Gee, J. P. (2007). (Forward). In D. Hutchison, Playing to learn: Video games in the classroom. London: Teacher Ideas Press.

Hartman, V. F. (1995). Technical and learning style preferences: Transitions through technology. VCCA Journal, Vol. 
9(2), pp. 18-20.

Hirsch, E. D. (1987). Cultural literacy: What every American needs to know. New York: Houghton Mifflin Company.

Honey, P. \& Mumford, A. (1982). The manual of learning styles. Maidenhead: Peter Honey.

Hutchison, D. (2007). Playing to learn: Video games in the classroom. London: Teacher Ideas Press.

Johnston, C. (2014). Fostering deeper learning, teaching and learning unit. Melbourne University: Faculty of Economics and Commerce, Universuty of Melbourne. Accessed on 6 April 2014, at: https://fbe.unimelb.edu.au/_data/assets/pdf_file/0007/634309/DEEPL1.pdf

Jones \& Bartlett. (2014). Teaching today's students. Sudbury, MA: Jones \& Bartlett Learning, Ascend Learning. Accessed online on 14 December 2014 at: http://www.samples.jbpub.com/9780763776121/76121_CH02_Page.pdf

Jukes, I. \& Dosai, A. (2006). Understanding digital children (DKs): Teaching \& learning in the new digital Landscape. The InfoSavvy Group. Accessed online on 9 December 2014 at: https://edorigami.wikispaces.com/file/view/Jukes+-+Understanding+Digital_Kids.pdf.

Jukes, I; McCain, T. \& Crockett, L. (2010). Understanding the digital generation: Teaching and learning in the new digital landscape. Melbourne, Vic: Hawker Brownlow Education.

Kasowitz-Scheer, A. \& Pasqualoni, M. (2002). Information literacy instruction in higher education: Trends and issues. ERIC Digest-ED465375. Accessed online on 14 December 2014 at: http://www.ericdigests.org/2003-1/information.htm.

Kelly, F. S; McCain, T. \& Jukes, I. (2009). Teaching the Digital Generation: No more cookie-cutter high schools. Melbourne, Vic: Hawker Brownlow Education.

King, A. (1993). From sage on the stage to guide on the side. College Teaching, Vol. 41(1), pp. 30 - 35. http://dx.doi.org/10.1080/87567555.1993.9926781

Kivunja, C. \& Power, A. (2006). A New Dynamic Paradigm for analyzing structural and cultural dynamics in an educational organization. Paper presented at the Annual Conference, Adelaide, Australian Association for Research in Education (AARE), 27 - 30 November.

Kivunja, C. (2014a). Theoretical perspectives of how Digital Natives learn. International Journal of Higher Education, Vol. 3(1), pp. 94 - 109. http://dx.doi.org/10.5430/ijhe.v3n1p94

Kivunja, C. (2014b). Do you want your students to be job-ready with 21st century skills? Change pedagogies: A paradigm shift from Vygotskyian social constructivism to critical thinking, problem solving and Siemens' digital connectivism. International Journal of Higher Education, Vol. 3(3), pp. 81-91. http://dx.doi.org/10.5430/ijhe.v3n3p81

Kivunja, C. (2014c). Innovative pedagogies in higher education to become effective teachers of 21st century skills: Unpacking the Learning and Innovations Skills Domain of the New Learning Paradigm, International Journal of Higher Education, Vol. 3(4), pp. 37 - 48. http://dx.doi.org/10.5430/ijhe.v3n4p37

Kivunja, C. (2015a). Teaching students to learn and to work well with $21^{\text {st }}$ century skills: Unpacking the Career and

Life Skills Domain of the New Learning paradigm, International Journal of Higher Education, Vol. 4(1), pp. 1 - 11. http://dx.doi.org/10.5430/ijhe.v4n1p1

Kivunja, C. (2015b). Innovative Methodologies for $21^{\text {st }}$ century learning, teaching and assessment: A convenience sampling investigation into the use of social media technologies in Higher Education, International Journal of Higher Education, Vol. 4(2), pp. 1 - 26. http://dx.doi.org/10.5430/ijhe.v4n2p1

Kolb, L. (2008). Toys to tools: Connecting student mobile phones to education, Moorabin, VIC: Hawker Brownlow.

Lenhart, A., Madden, M., \& Hitlin, P. (2005). Teens and technology: Youth are leading the transition to a fully wired and mobile nation. PEW Internet \& American Life Project. Accessed on 7 December 2014 at: http://www.pweinternet.org/-/media/Files/Reports/2005/PIP_Teens_Tech_July2005web.pdf

Levin, D., Arafeh, S., Lenhart, A. \& Rainie, L. (2002). The digital disconnect: The widening gap between Internet-savvy students and their schools, PEW Internet \& American Life Project. Retrieved on 7 December 2014, from: http://www.pewinternet.org/-/media//Files/Reports/2002/PIP_Schools_Internet_Report.pdf. 
McCombs, B. (2000). Assessing the role of educational technology in the teaching and learning process: A learner-centered Perspective. The Secretary's Conference on Educational Technology 2000: Measuring Impacts and Shaping the Future (Proceedings). (Alexandria, VA, September $11-12,2000$ ).

Medina, J. J. (2013). Brain rules: 12 principles for surviving and thriving at work, home, and school. Brunswick, VIC: Scribe Publications.

Meyers, N. M. \& Nulty, D. D. (2008). How to use (five) curriculum design principles to align authentic learning environments, assessment, students' approaches to thinking and learning outcomes. Assessment and Evaluation, Vol. 29(6), pp. 687-702.

Moje, E. B. (2000). To be part of the story: The literacy practices of gangsta adolescents. Teachers College Record, Vol. 102(3), pp. 652 - 690. http://dx.doi.org/10.1111/0161-4681.00071

Moje, E. B. \& Sutherland, L. M. (2003). The future of middle school literacy education. English Education, Vol. 35(2), pp. $149-164$.

Mouza, C. \& Lavigne, N. (Eds.). (2013). Emerging technologies for the classroom: A learning sciences perspective. New York: Springer Science+Businesss Media.

NEA. (2014). Preparing $21^{\text {st }}$ century students for a global society: An educators guide to the "Four Cs". National Education Association. Accessed online at: http://www.nea.org/assets/docs/A-Guide-to-Four-Cs.pdf on 26 August 2014.

P 21. (2009). P21 Framework Definitions. Partnership for 21st Century Skills (P 21), December 2009.

P 21. (2011). Partnership for 21st Century Skills (P21). Framework for 21st Century Learning. Retrieved from http://www.P21.org on July 10, 2014

Solomon, G. (2014). Education for the $21^{\text {st }}$ century: The basics, $21^{\text {st }}$ century connections. Accessed online, on 14 December 2014 at: http://www.smlcs.org/publications/21stcenturyeducation.pdf

P21. (2014). Framework for $21^{\text {st }}$ Century Learning. Accessed online on 14 December 2014 at: https://www.wvwc.edu/academics/gradprograms/ME/Framework_for_21st_Century_Learning.pdf

P21. (2014b). Learning for the $21^{\text {st }}$ Century: A Report and MILE Guide for $21^{\text {st }}$ Century Skills, Partnership for $21^{\text {st }}$ Century Skills. Accessed online on 26 August 2014 at: http://www.21stcenturyskills.org

Piaget, J. (1954). The construction of reality in the child. New York: Basic Books. http://dx.doi.org/10.1037/11168-000

PISA. (2003). The PISA framework for assessing ICT literacy: Draft report to Network A. Program for International Student Assessment. In P21-2014b. Learning for $21^{\text {st }}$ century, http://www.21stcenturyskills.org

Prensky, M. (2001). Digital Natives Digital Immigrants: Do they really think differently? On the Horizon, Vol. 9(6). http://dx.doi.org/10.1108/10748120110424843

Prensky, M. (2010). Teaching digital natives: Partnering for real learning. Melbourne: Hawker Brownlow Education.

Resnick, M. (2002). Rethinking learning in the digital age. In G. Kirkman (Ed.). The global information technology report: Readiness for the networked world. London: Oxford University Press.

Richardson, W. (2010). Blogs, wikis, podcasts and other powerful Web tools for classrooms, (3 ${ }^{\text {rd }}$ edn.). Moorabin, VIC: Hawker Brownlow.

Roscelle, J. P. \& Pea, R. (2002). A walk on the WILD side: How wireless handhelds may change CSCL. In G. Stahl (Ed.), Proceedings of the computer-supported collaborative learning conference (pp. 51 - 60), Hillsdale, NJ: Erbaum.

Roschelle, J., Courey, S., Patton, C. \& Murray, E. (2013). Dynabooks: Supporting teachers to engage all learners in key literacies. In C. Mouza, \& N. Lavigne. (2013) (Eds). Emerging technologies for the classroom: A learning sciences perspective, pp. 31 - 46, New York: Springer Science+Businesss Media.

SCONUL. (2011). The SCONUL Seven pillars of information literacy: A research lens for higher education, Society of College, National and University Libraries, (SCONUL), Working Group of Information Literacy. Accessed online at: http://www.sconul.ac.uk/groups/information_literacy/publications/rsearchlens.pdf On 14 December 2014. 
Smith, A. (1776). An inquiry into the nature and causes of the wealth of nations. Edited by R.H. Campbell and A.S. Skinner. London: Oxford University Press.

Solomon, G. (2014). Education for the $21^{\text {st }}$ century: The basics, $21^{\text {st }}$ century connections. Accessed online, on 14 December 2014 at: http://www.smlcs.org/publications/21stcenturyeducation.pdf

Speranza, A. (2014). Why schools are going Ga-Ga for Google. Australian Educational Leader Journal of the Australian Council for Educational Leaders, Vol. 36(2), pp. 53 - 55.

Squire, K. D. (2013). Mobile media learning: Ubiquitous computing environments for the mobile generation. In C. Mouza \& Lavigne, N. (Editors) (2013). Emerging technologies for the classroom: A learning sciences perspective. New York: Springer Science+Businesss Media.pp.187 - 202.

Stambler, L. G. (2013). Literacies for the Digital Age to teach in the K-12 classroom. Yale: Pier Institute, Yale University.

Tapscott, D. (1998). Grown up digital: The rise of the Net Generation. New York: McGraw-Hill.

Tapscott, D. (2009). Grown up digital: How the Net Generation is changing your world. New York: McGraw-Hill.

The New London Group. (1996). A pedagogy of multiliteracies: Designing social futures. Harvard Educational Review, Vol. 66(1), pp. $60-92$.

Trilling, B. \& Fadel, C. (2009). 21st century skills: Learning for life in our times. San Francisco, CA: Jossey-Bass.

UNESCO. (2002). US National Commission on Libraries and Information Science et al., Goals, objectives and

participant responsibilities. Meeting of experts on information literacy 2002. Accessed online on 1 October 2002, at: http://www.nclis.gov/libinter/infolitconf\&meet/goals-objectives-participant_responsibilities.html

Vygotsky, L. S. (1978). Mind in society: The development of higher psychological processes. Cambridge, MA: Harvard University Press.

Wagner, T. (2010). The global achievement gap: Why even our best schools don't teach the new survival skills our children need - and what we can do about it. New York Basic Books.

Walsh, L. L., Lemon, B., Black, R., Mangan, C. \& Collin, P. (2011). The role of technology in engaging disengaged youth: Final Report, Australia Flexible Learning Framework. Canberra: Commonwealth of Australia.

Willingham, D. T. (2009). Why don't students like school? A cognitive scientist answers questions about how the mind works and what it means for the classroom. San Francisco, CA: Jossey-Bass.

Yorke, M. (2003). Formative assessment in higher education: Moves towards theory and the enhancement of pedagogic practice. Higher Education, Vol. 45, pp. 477-501. http://dx.doi.org/10.1023/A:1023967026413

Zimmerman, B. J. (2000). Attaining self-regulation: A social cognitive perspective. In M. Boekaerts, P. R. Pintrich, \& M. Zeidner, (Eds.). Handbook of self-regulation, (pp. 13 - 39), San Diego, CA: Academic Press. http://dx.doi.org/10.1016/B978-012109890-2/50031-7 